\title{
Soil Biological Activity within Integrated and Ecological Management of Soil
}

\author{
Tatiana Števlíková - Soňa Javoreková - \\ Jana Vjatráková \\ Slovak Agricultural University in Nitra, Slovak Republic
}

\section{SUMMARY}

The effects of the integrated (IS) and ecological (ES) management of soil on chosen parameters of soil biological activity were investigated in the period 1999-2000. The following characteristics were determined: biomass of microorganisms $\left(C_{m i c}\right)$, dehydrogenase activity (DHA), an amount of potentially mineralizable nitrogen $\left(N_{\text {biol }}\right)$, and nitrification intensity. Soil samples were collected from a stationary field experiment established in 1990 on gley brown soil at the Experimental Station of Slovak Agricultural University, Nitra. For each field with a different crop rotations two fertilization treatments were selected: (a) no fertilization and (b) use of manure for silage maize and, within IS, also mineral fertilizers. There was a statistically significant difference at $\alpha=0.05$ in the amount of biologically released nitrogen $\left(N_{\text {biol }}\right)$ between both systems and in the nitrification intensity in favour of ES. A higher amount of microbial biomass $\left(C_{\text {mic }}\right)$ was noted for ES but without statistical significance. Cultivated crops and the timing of soil sampling were found to have the greatest effect on all the parameters observed in individual experimental years and within the two systems of soil management.

\section{INTRODUCTION}

Nutrient availability and crop yields are closely associated with the amount and activity of biological components of soils. Edaphon substantially participates in all processes conditioning soil fertility. It primarily degrades different organic substances, acts in humus synthesis, promotes nutrient availability for plants and the formation of soil structure. Irreplaceable is also its hygienic function and capability of producing physiologically active substances affecting the development and health of plants. These functions of soil organisms should be maintained, strengthened and utilized in systems of soil management. Because of the adverse effects of intensive, conventional agricultural systems on the environment, different alternatives to biological, ecological or organic farming systems are being developed which reduce this negative impact.

In recent years, many papers have been published in which these systems are compared and evaluated from different aspects (Beyer et al., 1992; Beyer et al., 1993; Friedel et al., 1996; Kandeler et al., 1999). There are various views on the suitability of the methods used to assess soil biological activity and its change due to different soil cultivation and fertilization methods, as well as the whole system of soil management. The most often used parameter is an amount of microbial biomass (Beyer et al., 1992; Šantrůčková, 1993; Friedel et al., 1996), which is usually supplemented by determing enzyme activity (Šíša, 1993; Beyer et al., 1993; Curci et al., 1997;
Bandick and Dick, 1999) or with some of the circulation processes of carbon and nitrogen (Friedel et al., 1996; Kandeler et al., 1999). A choice of sensitive indicators of quality reflecting the effects of soil management should also help those who cultivate soil and take an active part in sustaining agro-ecosystems.

\section{MATERIAL AND METHODS}

Within the stationary field experiment established on gley brown soil, the effects of two systems of soil management, namely the integrated system (IS) and the ecological system (ES), on soil biological activity were studied during the growing period of 19992000. The trial had been conducted since 1990 at the Experimental Station of Slovak Agricultural University (Nitra) in the locality of Dolná Malanta. The systems differed in crop rotation, fertilization method and protection against diseases, weeds and pests. In the IS, cereals made $50 \%$ and forage crops of several years, legumes and root crops $16.7 \%$ each. The ES comprised $33.3 \%$ of forage crops of several years, $33.3 \%$ of cereal crops and legumes and root crops, each $16.7 \%$. The plots selected from the experiment to study soil biological activity are presented in Table 1a. For each of these plots two fertilizer treatments were used: (a) no fertilization and (b) organic fertilization using manure for silage maize (\#) and within IS, it was also supplemented with mineral fertilizers for the purposes of balancing (Table 1b). Soil samples were collected 5-6 times from the 0-0.2 $\mathrm{m}$ layer during the vegetation period. After being passed through a $2 \mathrm{~mm}$ sieve, they were analysed for:

- basic soil characteristics: $\mathrm{C}_{\mathrm{ox}}$ as described by Turin (Arinuschkinova, 1961), $\mathrm{N}_{\mathrm{t}}$ using the distillation method of Joldbauer; $\mathrm{pH}$ potentiometrically, the reported $\mathrm{pH}$ values are for $1: 25(\mathrm{~W} / \mathrm{V})$ suspensions of air-dried soils in distilled water and $\mathrm{KCl}$ solution;

- biomass carbon of soil microorganisms $\left(\mathrm{C}_{\text {mic }}\right)$ using the fumigation extraction method as described by Vance et al. (1987);

- dehydrogenase activity (DHA) as described by Casida et al. (1964);

- $\mathrm{NH}_{4}{ }^{+} \mathrm{N}$ content in fresh samples and after incubation of soil samples for 14 days colorimetrically with the Nessler agent in the extract of $1 \% \mathrm{~K}_{2} \mathrm{SO}_{4}$;

- $\mathrm{NO}_{3}^{-}-\mathrm{N}$ content in fresh samples and after incubation of soil samples for 14 day colorimetrically with phenoldisulphone acid in the extract of $1 \% \mathrm{~K}_{2} \mathrm{SO}_{4}$. 
Samples were incubated at $28^{\circ} \mathrm{C}$ at a moisture content adjusted to $60 \%$ of water holding capacity. The amount of biologically released nitrogen $\left(\mathrm{N}_{\text {biol }}\right)$ and the nitrification intensity were determined from the values measured. Biologically mineralizable nitrogen means a gain of mineral $\mathrm{N}$ during incubation. Nitrification activity was calculated as different of $\mathrm{NO}_{3}^{-}-\mathrm{N}$ content in incubated samples and fresh samples.

For the statistical evaluation of results, the $\chi^{2}$ test of good conformity was used, then analysis of variance was used for comparing means of the basic set and Scheffe test for testing the differences in means. If analysis of variance did not guarantee correct results, Kruskal-Wallis test was used, which tests the critical values of differences in means as described by Dunn (Stehlíková and Škulecová, 1998).

\section{RESULTS AND DISCUSSION}

There are differences in cultivation methods, crop rotation, methods for protection against weeds and pests, fertilizers, and rates of fertilizer used by individual farming systems. Soil microorganisms and soil microbiological processes are then affected by the quantity and quality of plant residues placed in soil, their time and space distribution, a ratio of above-ground input to underground input of organic residues and changes in nutrient inputs (Beyer et al., 1992a, b; Friedel et al., 1996; Bandick and Dick, 1999).

One of the parameters which is most often studied for the purposes of evaluating the biological status of soil is the amount of microbial biomass (Šantrůčková, 1993). According to our results, the differences in the amount of microbial biomass in soil between IS and ES was found in the second experimental year only (Table 2). The values within ES were 35.48 mg C. $\mathrm{kg}^{-1}$ higher on average, but without statistical significance, in the fields where alfalfa, silage maize and pea (Pisum sativum) were grown (Table 5). An influence of the quality and amount of plant residues ploughed in soil has been confirmed for both systems. Within IS, the crops significantly affected the quantity of biomass in either of the experimental years, the greatest values being found for the soil under alfalfa in the year 2000 (199.28 mg C. $\mathrm{kg}^{-1}$ dry soil) and under bean with undersown alfalfa in 1999 (187.3 mg C. $\mathrm{kg}^{-1}$ dry soil) - Tables 6 and 7. As far as ES is concerned, the significant effect of crops was observed in 1999, with the highest value for the soil under wheat $\left(184.38 \mathrm{mg}\right.$ C. $\mathrm{kg}^{-1}$ dry soil). The dynamics of microbial biomass in soil within individual experimental years was affected by the timing of soil sampling (Tables 6 and 7). There was no statistical significance of differences between fertilization treatments (a, b) (Table 3).

Many authors consider biomass of soil microorganism together with enzyme activities to be a sensitive and suitable indicator of changes in soil as a consequence of anthropogenic interventions
(Friedel et al., 1996; Curci et al., 1997; Bandick and Dick, 1999). However, the views on suitability of further parameters are different. Beyer et al. (1993) mentioned that the dehydrogenase activity was very suitable for an assessment of effects of farming or a cultivation method on the microbiological condition of soil. It is rather dependent on the type of soil and its physical and chemical properties. Bandic and Dick (1999) state that the determination of $\beta$ glucosidase, which is also of microbiological/ecological importance, is very suitable for this purpose. Most authors, however, agreed on the fact that it must always be several simultaneously determined parameters that provide a more complex picture of the condition of soil biological component.

Based on our measurements, in spite of nonsignificant differences between the two systems of soil management for 2 years of observations (Table 5), we can conclude that DHA is a good indicator of general physiological processes of soil microflora. It sensitively reacts to changes in a supply of organic substances to soil in the form of post-harvest residues and root secretions. Also, changes in DHA activity of soil microflora have supported this fact (Table 4). Within ES, the effect of crop was highly significant in both of the experimental years, with the highest values for the soil under wheat in $1999(9.84 \mu \mathrm{g}$ TPF per $g$ dry soil per hour) and under alfalfa in 2000 (12.9 $\mu \mathrm{g}$ TPF per $\mathrm{g}$ dry soil per hour). As to IS, significant differences were found in the year 2000 when higher values were determined for the soil under alfalfa and wheat in comparison with maize. The biological soil activity expressed by DHA was affected by the time factor (statistically significant at $\alpha=0.01$ ) in both years and within both the systems of soil management, the highest values being observed for the soil samples taken in September (Tables 6 and 7).

Mineralizable nitrogen $\mathrm{N}_{\text {biol }}$ and nitrification showed a difference between the systems of soil management in favour of ES (Table 5). There was a difference in an amount of $\mathrm{N}_{\text {biol }}$ between both systems in 1999, with the average value $12.9 \mathrm{mg}$ $\mathrm{N}_{\mathrm{an}} \cdot \mathrm{kg}^{-1}$ dry soil for IS and $17.4 \mathrm{mg} \mathrm{N}_{\mathrm{an}} \cdot \mathrm{kg}^{-1}$ dry soil for ES.

In addition to other factors, the net content of inorganic nitrogen in soil is influenced by biological immobilization. On the other hand, the biological sorption by microorganisms of mineral nitrogen depends on their growth and propagation, thus being associated with the availability of carbon sources as well as the abiotic factors (Paul and Clark, 1989). It is evident that higher concentration of nitrogen in post-harvest residues, as a result of the cultivated crops within ES, influenced the amount of potentially mineralizable nitrogen. The influence of crops, however, was statistically significant only for IS in the year 2000. Also, the effect of fertilization treatments $(\mathrm{a}, \mathrm{b})$ was shown to be significant in IS that year (Table 7). Within ES, the amount of mineralisable nitrogen was greater and more balanced. It was similar to the average value of the 
fertilized treatment (b) of IS in 2000. The development of weather conditions, a source of organic nitrogenous substances and the intensity of nitrogen uptake by plants were found to affect the release dynamics of ammonium nitrogen and its oxidation. This manifested itself in a high significance level in both years (Tables 6 and 7). High amounts of potentially mineralisable nitrogen occurring in autumn, particularly within ES, are thought-provoking, as they represent a potential danger of losses. This danger is even higher as it is the case of nitrate form, which is also indicated by high nitrification activity of the soil of the experimental site.

The characteristic feature of soil microbial communities is their functional stability, resulting from their large number, generic diversity, high adaptation ability, as well as from internal regulation.
The homeostase variable - a range of any intervention during which its characteristics remain preserved - can be a qualitative expression of stability. Thus it is generally a positive result that the reaction of given microbial community of the experimental site as influenced by a soil management system has not exceeded this variable in the parameters studied.

We have used the data of Research Project of Scientific Grant's Agency of Ministry of Education and Slovak Academy of Science 1/61241/99 in the original scientific papers.

\section{Acknowledgments}

We acknowledge the assistance of laboratory assistant Dipl. Ing. Beáte Dobošovej, of the Department of Microbiology.

\section{REFERENCES}

Arinuškinova, E. V. (1961): Rukovodstvo po chimičeskom analizu počv. Izd. Moskovskovo Universiteta: 328s.

Bandick, A. K.-Dick, R. P. (1999): Field management effect on soil enzyme activities. Soil Biol. Bioch., 31. 1471-1479.

Beyer, L.-Wachendorf, C.-Balzer, F. M.-Balzer-Graf, U. C. (1992a): The effect of soil texture and soil management on microbial biomass and soil enzyme activities in arable soils of Northwest Germany. Agribiol. Res. 45. 3. 276-283.

Beyer, L.-Wachendorf, C.-Balzer, F. M.-Balzer-Graf, U. C. (1992b): The use of biological methods to determine the microbial activity of soil under cultivation. Biol. Fertil. Soils, 13. 242-247.

Beyer, L.-Wachendorf, C.-Elsner, D. C.-Knabe, R. (1993): Suitability of dehydrogenase activity assay an index of soil biological activity. Biol. Fertil. Soils, 16. 52-56.

Casida, L. E.-Klein, D. A.-Santaro, R. (1964): Soil dehydrogenase activity. Soil Sci., 98. 371-378.

Curci, M.-Pizzigallo, M. D. R.-Crecchio, C.-Minnini, R.-Ruggiero, P. (1997): Effects of conventional tillage on biochemical properties of soils. Biol. Fertil. Soils, 25. 1. 1-6.
Friedel, J. K.-Munch, J. C.-Fischer, W. R. (1996): Soil microbial properties and the assessment of available soil organic matter in a haplic luvisol after several years of different cultivation and crop rotation. Soil Biol. Biochem., 28. 4-5. 479-488.

Kandeler, E.-Tscherko, D.-Spiegel, H. (1999): Long-term monitoring of microbial biomass, $\mathrm{N}$ mineralisation and enzyme activities of a chernozem under different tillage management. Biol. Fertil. Soils, 28. 4. 343-351.

Paul, E. A.-Clark, F. E. (1989): Soil microbiology and biochemistry. San Diego, California: Academic Press, 264.

Šantrůčková, H. (1993): Mikrobní biomasa jako ukazatel biologické aktivity půdy. Rostl. Výr., 39. 9. 797-788.

Šíša, R. (1993): Enzymová aktivita půdy jako ukazatel její biologické aktivity. Rostl. Výr., 39. 9. 817-825.

Stehlíková, B.-Škulecová, M. (1999): Statgraphics. Nitra: Vydavatel'ské a edičné stredisko SPU, 176s.

Vance, E. D.-Brookes, P. C.-Jenkinson, D. W. (1987): An extraction method for measuring soil microbial biomass $\mathrm{C}$. Soil Biol. Biochem., 19. 703-707.

Table 1a: Crop rotation in chosen fields of integrated and ecological systems

\begin{tabular}{|c|l|l|l|l|l|l|}
\hline \multirow{2}{*}{ Year } & \multicolumn{3}{|c|}{ Integrated system } & \multicolumn{3}{c|}{ Ecological system } \\
\cline { 2 - 7 } & \multicolumn{1}{|c|}{ Field I } & \multicolumn{1}{|c|}{ Field V } & \multicolumn{1}{c|}{ Field VII } & \multicolumn{1}{c|}{ Field II } & \multicolumn{1}{c|}{ Field V } & Field VII \\
\hline 1999 & Bean + alfalfa & spring barley & winter wheat & bean + alfalfa & pea & winter wheat \\
\hline 2000 & Alfalfa & winter wheat & silage maize & alfalfa & maize & \\
\hline
\end{tabular}

\# - farmyard manure 40 t.ha $^{-1}$

Table 1b: Application of mineral fertilizers in integrated system

\begin{tabular}{|c|c|c|c|c|}
\hline \multirow{2}{*}{ Crop } & \multirow{2}{*}{ Year } & \multicolumn{3}{|c|}{ Mineral fertilizers (kg.ha ${ }^{-1}$ ) } \\
\hline & & $\mathbf{N}$ & $\mathbf{P}$ & $\mathbf{K}$ \\
\hline bean + alfalfa & \multirow{3}{*}{1999} & 30 & 20 & 20 \\
\hline spring barley & & - & 15 & 30 \\
\hline winter wheat & & 19 & - & - \\
\hline Alfalfa & \multirow{3}{*}{2000} & - & - & - \\
\hline winter wheat & & 30 & 5 & 20 \\
\hline silage maize & & 72 & 5 & 20 \\
\hline
\end{tabular}


Table 2: Basic soil characteristics within the integrated and ecological system soil management (average values)

\begin{tabular}{|c|c|c|c|c|c|c|c|c|c|}
\hline $\begin{array}{c}\text { Soil } \\
\text { Management }\end{array}$ & Year & $\begin{array}{l}\mathrm{C}_{\mathrm{ox}} \\
{[\%]}\end{array}$ & $\begin{array}{c}\mathbf{N}_{t} \\
{[\%]}\end{array}$ & $\mathrm{pH}_{(\mathrm{H} 2 \mathrm{O})}$ & $\mathbf{p H}_{(\mathrm{KCl})}$ & $\mathrm{C}_{\text {mic }}$ & DHA & $\mathbf{N}_{(\text {biol })}$ & $\begin{array}{l}\text { Nitrifi- } \\
\text { cation }\end{array}$ \\
\hline \multirow[t]{2}{*}{ IS +treat.a } & 1999 & 1.21 & 0.138 & 6.62 & 5.32 & 168.17 & 5.00 & 12.14 & 12.43 \\
\hline & 2000 & 1.20 & 0.163 & 6.98 & 5.19 & 169.67 & 5.53 & 13.28 & 13.77 \\
\hline \multirow[t]{2}{*}{ IS + treat.b } & 1999 & 1.31 & 0.144 & 6.66 & 5.40 & 172.59 & 5.04 & 13.66 & 14.02 \\
\hline & 2000 & 1.36 & 0.170 & 6.46 & 5.37 & 157.30 & 6.19 & 17.87 & 19.23 \\
\hline \multirow[t]{2}{*}{$\mathrm{ES}+$ treat.a } & 1999 & 1.25 & 0.146 & 6.58 & 5.30 & 164.41 & 5.42 & 17.65 & 17.96 \\
\hline & 2000 & 1.27 & 0.167 & 6.40 & 5.43 & 213.37 & 6.13 & 18.23 & 18.93 \\
\hline \multirow[t]{2}{*}{$\mathrm{ES}+$ treat.b } & 1999 & 1.29 & 0.151 & 6.62 & 5.39 & 167.61 & 5.70 & 16.63 & 17.02 \\
\hline & 2000 & 1.28 & 0.166 & 6.47 & 5.41 & 184.56 & 5.59 & 16.60 & 17.29 \\
\hline
\end{tabular}

$\mathrm{C}_{\text {mic }}$ in mg per kg dry soil

DHA in $\mu \mathrm{g}$ TPF per g dry soil per hour

$\mathrm{N}_{\text {biol }}$ in $\mathrm{mg}$ per $\mathrm{kg}$ dry soil

IS = integrated system of soil management

$\mathrm{ES}=$ ecological system of soil management

Nitrification in mg per kg dry soil

treat. $\mathrm{a}=$ treatment without fertilization

treat. $b=$ treatment with fertilization

Table 3: The basic variance-statistical characteristics and results from distribution fitting in soil under integrated and ecological management in 1999

\begin{tabular}{|c|c|c|c|c|c|c|c|c|}
\hline \multirow{3}{*}{$\begin{array}{c}\text { Statistical } \\
\text { characteristics }\end{array}$} & \multicolumn{8}{|c|}{ Microbial characteristics } \\
\hline & \multicolumn{2}{|c|}{$\begin{array}{l}\text { Soil microbial biomass } \\
\text { [mg C.kg }{ }_{\text {soil dry matter] }}\end{array}$} & \multicolumn{2}{|c|}{$\begin{array}{c}\text { Nitrification } \\
{\left[\text { [mg.kg }^{-1}{ }_{\text {soil dry matter }]}\right.}\end{array}$} & \multicolumn{2}{|c|}{$\begin{array}{l}\text { Soil dehydrogenase activity } \\
{\left[\mu \mathrm{gTPF} \cdot \mathrm{g}^{-1}{ }_{\text {soil dry matter }} \cdot \text { hour }^{-1}\right]}\end{array}$} & \multicolumn{2}{|c|}{$\begin{array}{c}\text { Biologically released } \\
\text { nitrogen } \\
{\left[\mathrm{mg} \mathrm{kg}_{\text {soil dry matter }]}^{-1}\right.} \\
\end{array}$} \\
\hline & IS & ES & IS & ES & IS & ES & IS & ES \\
\hline $\mathrm{n}$ & 36 & 36 & 36 & 36 & 36 & 36 & 36 & 36 \\
\hline $\mathrm{x}$ & 170.38 & 166.00 & 13.22 & 17.49 & 5.02 & 5.56 & 12.90 & 17.14 \\
\hline Minimum & 107.66 & 103.38 & 1.38 & 7.40 & 1.89 & 2.63 & 1.49 & 7.16 \\
\hline Maximum & 243.80 & 236.02 & 49.53 & 61.53 & 9.11 & 9.84 & 49.09 & 60.99 \\
\hline $\mathrm{s}$ & 31.62 & 27.64 & 8.42 & 13.15 & 1.87 & 1.64 & 8.42 & 13.12 \\
\hline $\mathrm{s}_{\mathrm{x}}$ & 5.27 & 4.61 & 1.40 & 2.19 & 0.31 & 0.27 & 1.40 & 2.19 \\
\hline$s^{2}$ & 999.57 & 763.80 & 70.84 & 172.95 & 3.50 & 2.70 & 70.84 & 172.18 \\
\hline $\mathrm{v}[\%]$ & 18.56 & 16.65 & 63.67 & 75.21 & 37.26 & 29.56 & 65.24 & 76.55 \\
\hline \multicolumn{9}{|l|}{$\begin{array}{l}\text { Distribution } \\
\text { fitting }\end{array}$} \\
\hline$\chi^{2}$ & 0.53 & 1.24 & 30.14 & 36.31 & 0.30 & 4.87 & 25.86 & 35.42 \\
\hline P-value & 0.77 & 0.54 & $1.29 .10^{-6}$ & $1.30 .10^{-8}$ & 0.86 & 0.09 & $2.43 .10^{-6}$ & $2.03 .10^{-8}$ \\
\hline
\end{tabular}

IS - Integrated management

ES - Ecological management

$\mathrm{n}$ - number of observation

$\mathrm{x}$ - average

$\mathrm{s}$ - standard deviation
$\mathrm{S}_{\mathrm{x}}$ - standard mean error

$\mathrm{s}^{2}$ - variance

$\mathrm{v} \%$ - coefficient of variation

$\chi^{2}$ - chí square test 
Table 4: Analysis of variance according to ANOVA for soil microbial biomass and soil dehydrogenase activity and Kruskal-Wallis test for nitrification and biologically released nitrogen in 1999

\begin{tabular}{|c|c|c|c|c|}
\hline Source of variability & Count & f & Test statistic & Significant level \\
\hline \multicolumn{5}{|l|}{ Soil microbial biomass } \\
\hline Fertilization IS & 18 & 1 & 0.31 & 0.59 \\
\hline Fertilization ES & 18 & 1 & 0.21 & 0.66 \\
\hline Sampling IS & 6 & 5 & 4.96 & $0.00^{++}$ \\
\hline Sampling ES & 6 & 5 & 2.39 & 0.07 \\
\hline Crop IS & 12 & 2 & 4.56 & $0.02^{+}$ \\
\hline Crop ES & 12 & 2 & 9.85 & $0.00^{++}$ \\
\hline \multicolumn{5}{|l|}{ Nitrification } \\
\hline Fertilization IS & 18 & 1 & 0.29 & 0.59 \\
\hline Fertilization ES & 18 & 1 & $1.00 .10^{-3}$ & 0.98 \\
\hline Sampling IS & 6 & 5 & 12.39 & $0.03^{+}$ \\
\hline Sampling ES & 6 & 5 & 22.92 & $3.50 .10^{-4++}$ \\
\hline Crop IS & 12 & 2 & 4.97 & 0.08 \\
\hline Crop ES & 12 & 2 & 1.85 & 0.40 \\
\hline \multicolumn{5}{|l|}{ Soil dehydrogenase activity } \\
\hline Fertilization IS & 18 & 1 & 0.03 & 0.88 \\
\hline Fertilization ES & 18 & 1 & 1.64 & 0.21 \\
\hline Sampling IS & 6 & 5 & 42.04 & $0.00^{++}$ \\
\hline Sampling ES & 6 & 5 & 29.78 & $0.00^{++}$ \\
\hline Crop IS & 12 & 2 & 1.68 & 0.21 \\
\hline Crop ES & 12 & 2 & 16.95 & $0.00^{++}$ \\
\hline \multicolumn{5}{|l|}{ Biologically released nitrogen } \\
\hline Fertilization IS & 18 & 1 & 0.38 & 0.54 \\
\hline Fertilization ES & 18 & 1 & 0.01 & 0.91 \\
\hline Sampling IS & 6 & 5 & 12.88 & $0.02^{+}$ \\
\hline Sampling ES & 6 & 5 & 22.74 & $3.78 .10^{-4++}$ \\
\hline Crop IS & 12 & 2 & 4.42 & 0.11 \\
\hline Crop ES & 12 & 2 & 1.74 & 0.42 \\
\hline
\end{tabular}

f - degree of freedom

${ }^{+} \mathrm{p}<0.05 ;{ }^{++} \mathrm{p}<0.01$

Table 5: The basic variance-statistical characteristics and results from distribution fitting in soil under integrated and ecological management in $\mathbf{2 0 0 0}$

\begin{tabular}{|c|c|c|c|c|c|c|c|c|}
\hline \multirow{3}{*}{$\begin{array}{c}\text { Statistical } \\
\text { characteristics }\end{array}$} & \multicolumn{8}{|c|}{ Microbial characteristics } \\
\hline & \multicolumn{2}{|c|}{$\begin{array}{l}\text { Soil microbial biomass } \\
{\left[\mathrm{mg} \mathrm{C} \cdot \mathrm{kg}^{-1}{ }_{\text {soil dry matter }]}\right.}\end{array}$} & \multicolumn{2}{|c|}{$\begin{array}{l}\text { Nitrification } \\
{\left[\mathrm{mg}^{-k^{-1}}{ }_{\text {soil dry matter }]}\right.}\end{array}$} & \multicolumn{2}{|c|}{$\begin{array}{l}\text { Soil dehydrogenase activity } \\
{\left[\mu \mathrm{gTPF}^{-1} \mathrm{~g}^{-1} \text { soil dry matter.hour }{ }^{-1}\right]}\end{array}$} & \multicolumn{2}{|c|}{ 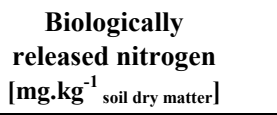 } \\
\hline & IS & ES & IS & ES & IS & ES & IS & ES \\
\hline $\mathrm{n}$ & 30 & 30 & 30 & 30 & 30 & 30 & 30 & 30 \\
\hline $\mathrm{x}$ & 163.49 & 198.97 & 16.50 & 18.11 & 5.86 & 5.86 & 15.57 & 17.41 \\
\hline Minimum & 102.33 & 106.5 & 4.05 & 8.43 & 2.16 & 2.36 & 3.34 & 7.18 \\
\hline Maximum & 278.84 & 326.01 & 36.61 & 26.45 & 10.41 & 12.09 & 33.72 & 25.89 \\
\hline $\mathrm{s}$ & 48.08 & 54.58 & 7.78 & 5.36 & 2.23 & 2.76 & 7.01 & 5.23 \\
\hline $\mathrm{S}_{\mathrm{x}}$ & 8.78 & 9.97 & 1.42 & 0.98 & 0.41 & 0.50 & 1.28 & 0.96 \\
\hline $\mathrm{s}^{2}$ & 2311.23 & 2979.14 & 60.47 & 28.78 & 4.95 & 7.64 & 49.11 & 27.36 \\
\hline $\mathrm{v}[\%]$ & 29.41 & 27.43 & 47.11 & 29.62 & 38.00 & 47.18 & 45.00 & 30.04 \\
\hline \multicolumn{9}{|l|}{$\begin{array}{l}\text { Distribution } \\
\text { fitting }\end{array}$} \\
\hline$\chi^{2}$ & 4.09 & 0.14 & 3.81 & 2.62 & 1.64 & 0.74 & 5.24 & 1.61 \\
\hline $\mathrm{P}$-value & 0.13 & 0.70 & 0.05 & 0.27 & 0.20 & 0.39 & 0.02 & 0.45 \\
\hline
\end{tabular}


Table 6: Analysis of variance according to ANOVA for soil microbial biomass, nitrification, soil dehydrogenase activity and biologically released nitrogen in $\mathbf{2 0 0 0}$

\begin{tabular}{|c|c|c|c|c|}
\hline Source of variability & Count & $\mathbf{f}$ & Test statistic & Significant level \\
\hline \multicolumn{5}{|l|}{ Soil microbial biomass } \\
\hline Fertilization IS & 15 & 1 & 1.01 & 0.33 \\
\hline Fertilization ES & 15 & 1 & 3.24 & 0.09 \\
\hline Sampling IS & 6 & 4 & 3.37 & $0.03^{+}$ \\
\hline Sampling ES & 6 & 4 & 3.31 & $0.03^{+}$ \\
\hline Crop IS & 10 & 2 & 11.10 & $0.00^{++}$ \\
\hline Crop ES & 10 & 2 & 3.23 & 0.06 \\
\hline \multicolumn{5}{|l|}{ Nitrification } \\
\hline Fertilization IS & 15 & 1 & 12.33 & $0.00^{++}$ \\
\hline Fertilization ES & 15 & 1 & 1.51 & 0.23 \\
\hline Sampling IS & 6 & 4 & 14.59 & $0.00^{++}$ \\
\hline Sampling ES & 6 & 4 & 9.37 & $0.00^{++}$ \\
\hline Crop IS & 10 & 2 & 2.04 & 0.15 \\
\hline Crop ES & 10 & 2 & 0.64 & 0.54 \\
\hline \multicolumn{5}{|l|}{ Soil dehydrogenase activity } \\
\hline Fertilization IS & 15 & 1 & 4.88 & $0.04^{+}$ \\
\hline Fertilization ES & 15 & 1 & 5.83 & $0.03^{+}$ \\
\hline Sampling IS & 6 & 4 & 37.15 & $0.00^{++}$ \\
\hline Sampling ES & 6 & 4 & 116.02 & $0.00^{++}$ \\
\hline Crop IS & 10 & 2 & 20.24 & $0.00^{++}$ \\
\hline Crop ES & 10 & 2 & 45.92 & $0.00^{++}$ \\
\hline \multicolumn{5}{|l|}{ Biologically released nitrogen } \\
\hline Fertilization IS & 15 & 1 & 12.05 & $0.00^{++}$ \\
\hline Fertilization ES & 15 & 1 & 1.59 & 0.22 \\
\hline Sampling IS & 6 & 4 & 16.70 & $0.00^{++}$ \\
\hline Sampling ES & 6 & 4 & 9.81 & $0.00^{++}$ \\
\hline Crop IS & 10 & 2 & 3.78 & $0.04^{+}$ \\
\hline Crop ES & 10 & 2 & 0.35 & 0.71 \\
\hline
\end{tabular}

Table 7: Analysis of variance according to ANOVA for soil microbial biomass and Kruskal-Wallis test for nitrification, soil dehydrogenase activity and soil biologically released nitrogen in years 1999 and 2000

\begin{tabular}{|c|c|c|c|c|}
\hline Source of variability & Count & $\mathbf{f}$ & Test statistic & Significant level \\
\hline \multicolumn{5}{|l|}{ Soil microbial biomass } \\
\hline Fertilization & 33 & 3 & 0.64 & 0.53 \\
\hline Soil management & 66 & 1 & 3.45 & 0.07 \\
\hline \multicolumn{5}{|l|}{ Nitrification } \\
\hline Fertilization & 33 & 3 & 6.41 & 0.09 \\
\hline Soil management & 66 & 1 & 4.12 & $0.04^{+}$ \\
\hline \multicolumn{5}{|l|}{ Soil dehydrogenase activity } \\
\hline Fertilization & 33 & 3 & 0.51 & 0.92 \\
\hline Soil management & 66 & 1 & 0.20 & 0.92 \\
\hline \multicolumn{5}{|l|}{ Biologically released nitrogen } \\
\hline Fertilization & 33 & 3 & 8.09 & $0.04^{+}$ \\
\hline Soil management & 66 & 1 & 5.95 & $0.02^{+}$ \\
\hline
\end{tabular}

